Communication

\title{
Enzymatic Synthesis of Thioesters from Thiols and Vinyl Esters in a Continuous-Flow Microreactor
}

\author{
Nani Zhou ${ }^{1}{ }^{(\mathbb{D})}$, Le Shen ${ }^{1}{ }^{(\mathbb{D}}$, Zhen Dong ${ }^{1}{ }^{(\mathbb{D})}$, Jiahong Shen ${ }^{1}{ }^{(\mathbb{D}}$, Lihua Du ${ }^{1, *}$ and Xiping Luo ${ }^{2, *}$ \\ 1 College of Pharmaceutical Science, Zhejiang University of Technology, Hangzhou 310014, China; \\ zhounani@zjut.edu.cn (N.Z.); shenle@zjut.edu.cn (L.S.); dongzhen@zjut.edu.cn (Z.D.); \\ shenjiahong@zjut.edu.cn (J.S.) \\ 2 Department of Environmental Science and Technology, Zhejiang A\&F University, Hangzhou 311300, China \\ * Correspondence: orgdlh@zjut.edu.cn or orgdlh@gmail.com (L.D.); luoxiping@zafu.edu.cn (X.L.); \\ Tel.: +86-571-189-6906-9399 (L.D.)
}

Received: 16 May 2018; Accepted: 14 June 2018; Published: 16 June 2018

\begin{abstract}
The preparation of thioesters through the lipase-catalysed transesterification reaction of thiols with vinyl carboxyl esters is described. The reactions were carried out by Lipase TL IM from Thermomyces lanuginosus as a catalyst and performed under a continuous flow microreactor. We first found that lipase TL IM can be used in the reaction of thioester synthesis with high efficiency. Various reaction parameters were investigated including substrate molar ratio, reaction time, and temperature. Maximum conversion (96\%) was obtained under the optimal condition of a substrate molar ratio of 1:2 (4-methylbenzyl mercaptan:vinyl esters) at $50{ }^{\circ} \mathrm{C}$ for about $30 \mathrm{~min}$. Compared with other methods, the salient features of this work include mild reaction conditions $\left(50^{\circ} \mathrm{C}\right)$, short reaction times $(30 \mathrm{~min})$, high yields, and environment-friendliness.
\end{abstract}

Keywords: enzymatic synthesis; thioester synthesis; flow chemistry; microreactor

\section{Introduction}

Flow chemistry [1-7] has attracted significant attention from researchers from both academia and industry. Various benefits over conventional batch processes include increased controllability, safety, and selectivity because of improved heat and mass transfer and shorter residence times. In particular, utilizing immobilized enzyme catalysts in microreactors is recognized as the most prioritized consideration of key green engineering areas for chemical synthesis [8-14]. In recent years, there has been demand for enzymatic microreaction devices in several fields, especially for biotransformation. Several enzymatic syntheses in microreactors have been reported [15-20].

Thioesters are important building blocks for organic synthesis [21] and chemical biology [22]. They are valuable intermediates in food, medicinal, and cosmetic chemistry, and in the production of new materials [23-25]. Many works on the synthesis of thioesters have been reported [26-31]. The most common catalysts reported for organic transformation of thioesters are triflates [32], Lewis acids [33], or lanthanide catalysts [34], etc. Unfortunately, with very few exceptions, all of these methods implicate toxic and hazardous reagents, harsh conditions, or uncommon starting materials. Therefore, it is important to find a new, simple, and environmentally friendly method for the preparation of thioesters.

Biocatalysis as an efficient and green biotransformation tool in organic synthesis that has attracted much attention of chemists and biochemists [35-38]. Especially, catalytic promiscuity in biocatalysis, which means using old enzymes to form new bonds and follow new pathways, was greatly extended and expanded rapidly [39-41]. Some enzymes, such as D-amino acylase from Escherichia coli (DA), have been applied to the synthesis of thioesters, but it requires a longer reaction time $(48 \mathrm{~h})$ to achieve the desired result [42]. Additinoally, only amino acylase was suitable for the synthetic reaction of 
thioesters, while lipase from Candida antarctica catalysed the reaction to Markovnikov addition. In the interest of developing mild methodologies for the synthesis of thioesters, we envisaged modifying our procedure to achieve a continuous flow microreactor protocol for the synthesis of thioesters. Specifically, we directed our attention towards the development of an enzymatic microreactor strategy involving lipase TL IM from Thermomyces lanuginosus as a catalyst (Scheme 1). The aim of this paper is to investigate, under a continuous-flow microreactor, the effect of various reaction parameters on the reaction conversion.

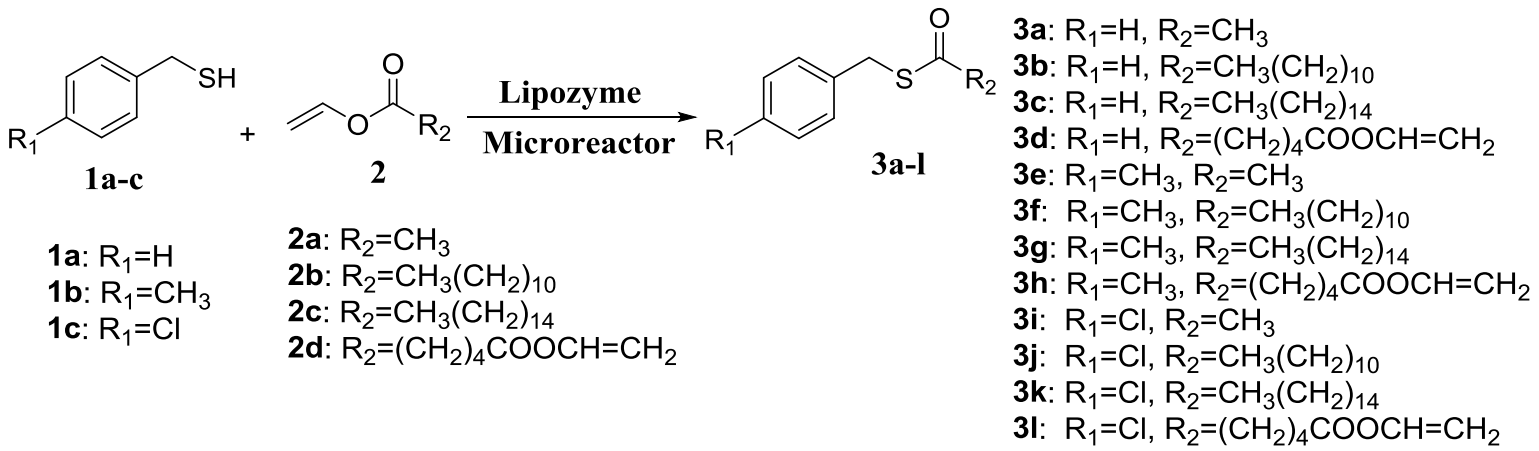

Scheme 1. Enzymatic synthesis of thioesters from thiols and vinyl esters in a continuous flow microreactor.

\section{Results and Discussion}

\subsection{Experimental Setup}

The enzymatic synthesis of thioesters from thiols and vinyl esters in a continuous-flow microreactor is described in Figure 1. We first examined the reactions using a continuous-flow microreactor system composed of a Y-shaped micromixer $(\Phi=1.8 \mathrm{~mm}$; M) and a microtube reactor $(\mathrm{R})$ shown in Figure 1 . A $3.1 \mathrm{~mL}$ PFA reactor coil (2 mm I. D.) was constructed and reagents were introduced by two separate feed streams. Reagent feed $1(10 \mathrm{~mL})$ with the thiol solution and reagent feed $2(10 \mathrm{~mL})$ with vinyl esters were mounted in DMSO, respectively. Lipozyme TL IM from Thermomyces lanuginosus (catalyst reactivity: $250 \mathrm{IUN} \cdot \mathrm{g}^{-1}$, particle diameter: $0.3-1.0 \mathrm{~mm}$ ) was filled in the microtube (R). A water bath was applied to control the temperature of this reaction by immersion of reactor coil in water. After initial optimization, it was found that the target thioesters (3a-31) could be obtained, after only a thirty minutes residence time, in excellent yield ( $\sim 86 \%)$ after separation and purification (Table 1$)$.

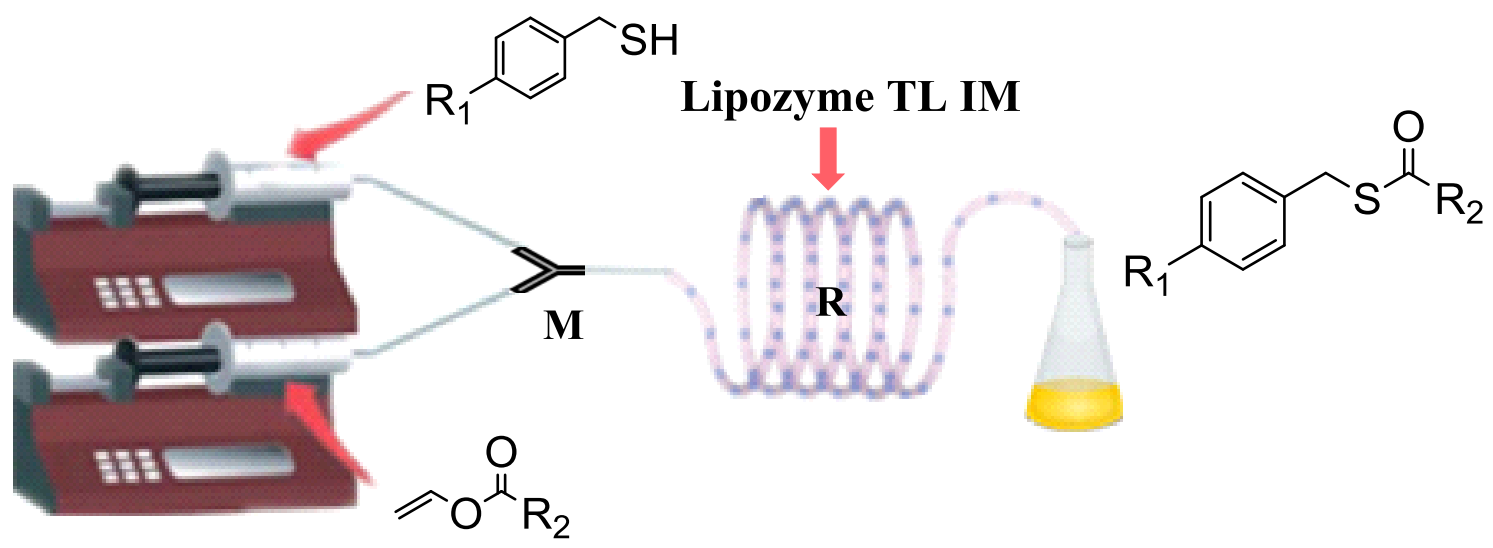

Figure 1. Experimental setup for the synthesis of thioesters catalysed by Lipozyme TL IM from Thermomyces lanuginosus in a continuous-flow microreactor. 
Table 1. Shaker and continuous flow synthesis of thioesters catalysed by Lipozyme TL IM.

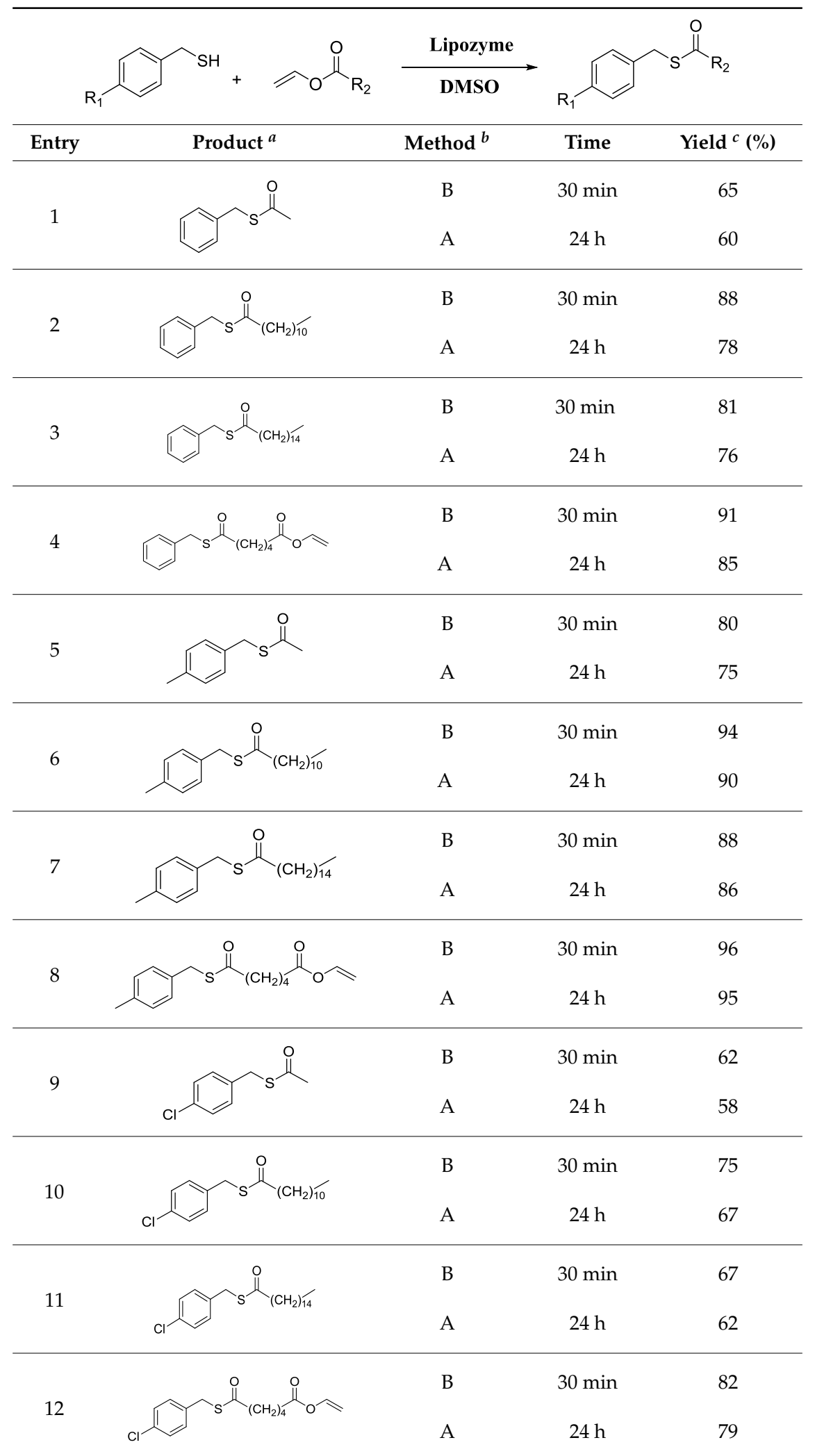

${ }^{a}$ Reactions and the structure of the products (3a-31) see Scheme $1 .{ }^{b}$ Method A: Shaker reactor, benzyl mercaptan $(1 \mathrm{mmol})$ and vinyl esters $(3 \mathrm{mmol})$ were added to $5 \mathrm{~mL}$ DMSO at $50^{\circ} \mathrm{C}$. Lipozyme TL IM $\left(0.22 \mathrm{~g}, 44 \mathrm{mg} \mathrm{mL}^{-1}\right)$, $24 \mathrm{~h}$. Method B: continuous flow microreactor, $10.4 \mu \mathrm{L} \mathrm{min}^{-1}$ feed 1 (4 mmol thiol derivatives in $10 \mathrm{~mL}$ DMSO) and $10.4 \mu \mathrm{L} \mathrm{min}{ }^{-1}$ feed $2\left(8 \mathrm{mmol}\right.$ vinyl esters in $10 \mathrm{~mL} \mathrm{DMSO}$ ) at $50{ }^{\circ} \mathrm{C}$ (residence time $30 \mathrm{~min}$ ), Lipozyme TL IM $\left(0.87 \mathrm{~g}, 44 \mathrm{mg} \mathrm{mL}^{-1}\right) \cdot{ }^{c}$ Isolated yield. 


\subsection{Molar Ratio (Thiols:Vinyl Esters) Effect}

We begin to explore the effects of various reaction parameters on the lipase-catalysed transesterification reaction of thiols with vinyl esters performed under a continuous flow microreactor. In our initial investigation, in order to ascertain the effect of molar ratio (thiols:vinyl esters) on the thioesters synthesis reaction in a microreactor, the thioester synthesis reaction of benzyl mercaptan and vinyl laurate was used as a model reaction. We tried substrate molar ratios (benzyl mercaptan:vinyl laurate) from 1:1 to 1:4. As we can see from Figure 2, the reaction conversion is $61 \%$ when the substrate molar ratio is 1:1. With the increase of vinyl laurate, the reaction conversion increases, too. The best result was obtained when the molar ratio reached 1:2. Considering the optimal reaction conversion and economy of the reaction, we decide to use the substrate molar ratio of 1:2 as the best molar ratio for the next experiment.

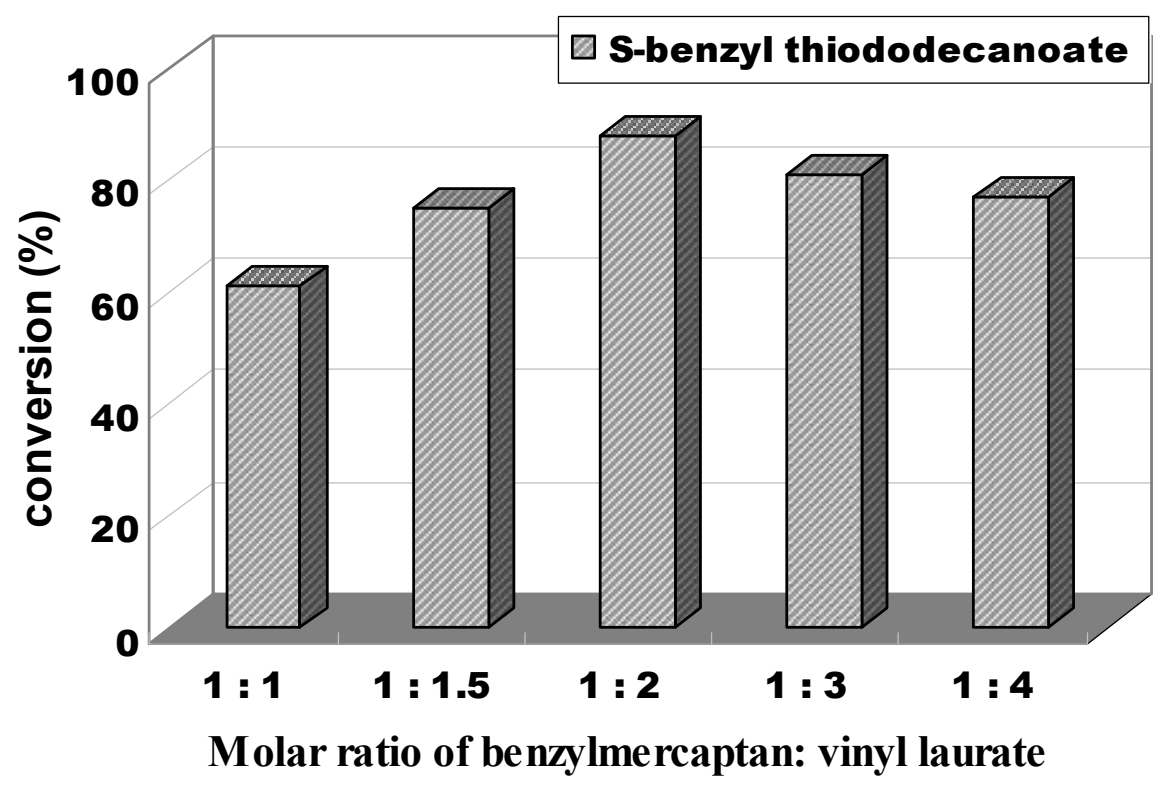

Figure 2. The influence of substrate molar ratio (benzyl mercaptan:vinyl laurate) on the enzymatic synthesis of thioesters in a continuous flow microreactor: $10.4 \mu \mathrm{L} \mathrm{min}{ }^{-1}$ feed 1 ( 4 mmol thiol derivatives in $10 \mathrm{~mL}$ DMSO) and $10.4 \mu \mathrm{L} \mathrm{min}{ }^{-1}$ feed $2\left(4-16 \mathrm{mmol}\right.$ vinyl esters in $10 \mathrm{~mL} \mathrm{DMSO}$ ) at $50{ }^{\circ} \mathrm{C}$ (residence time $30 \mathrm{~min})$, Lipozyme TL IM $\left(0.87 \mathrm{~g}, 44 \mathrm{mg} \mathrm{mL}^{-1}\right)$.

\subsection{Reaction Temperature Effect}

The temperature is another important factor for the enzymatic reactions, due to their effects on the enzyme stability and reaction rate, especially when the reaction conducted in a microreactor. After we find the optimum substrate molar ratio of the reaction, we continue to examine the effect of temperature on the lipase-catalysed thioester synthesis under a continuous flow microreactor. We adjusted the temperature from $40{ }^{\circ} \mathrm{C}$ to $60{ }^{\circ} \mathrm{C}$ to find the effect of temperature on the reaction conversion. As we can see from Figure 3, when the reaction was carried out at $40{ }^{\circ} \mathrm{C}$, the reaction conversion is only $65 \%$. With the increase of reaction temperature, the reaction conversion has also been obviously improved. When the reaction is controlled at $50{ }^{\circ} \mathrm{C}$, the thioester synthesis can achieve the optimal conversion of $88 \%$. Considering the optimal reaction conversion and the safety and operability of the reaction, we choose $50^{\circ} \mathrm{C}$ as the most suitable reaction temperature for the following study of the enzymatic thioester synthesis in a continuous flow microreactor. 


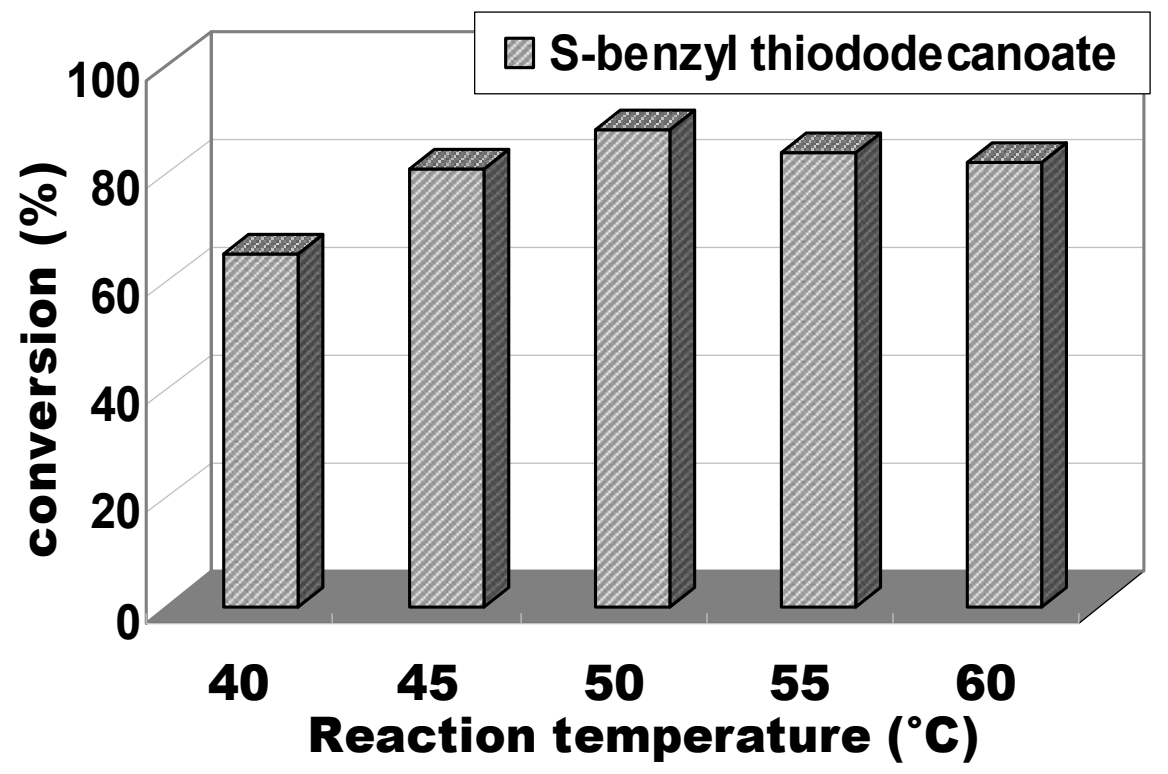

Figure 3. The influence of reaction temperature $\left({ }^{\circ} \mathrm{C}\right)$ on the enzymatic synthesis of thioesters in a continuous flow microreactor: $10.4 \mu \mathrm{L} \mathrm{min}{ }^{-1}$ feed 1 (4 mmol thiol derivatives in $\left.10 \mathrm{~mL} \mathrm{DMSO}\right)$ and $10.4 \mu \mathrm{L} \mathrm{min}^{-1}$ feed 2 ( $8 \mathrm{mmol}$ vinyl esters in $10 \mathrm{~mL} \mathrm{DMSO}$ ) at different reaction temperature (residence time $30 \mathrm{~min})$, Lipozyme TL IM $\left(0.87 \mathrm{~g}, 44 \mathrm{mg} \mathrm{mL}^{-1}\right)$.

\subsection{Reaction Time/Flow Rate Effect}

Reaction time/flow rate often play an important role in enzymatic reaction performed in a continuous flow microreactor. The lipase-catalysed thioester synthesis from benzyl mercaptan and vinyl laurate under a continuous flow microreactor was conducted in 20-40 min and the results are shown in Figure 4. It was found that the best conversion can be reached in $30 \mathrm{~min}$, at a flow rate of $20.8 \mu \mathrm{L} \mathrm{min}{ }^{-1}$. Thus, we chose $30 \mathrm{~min}$ (flow rate $20.8 \mu \mathrm{L} \mathrm{min}^{-1}$ ) as the optimum reaction time for the following study of enzymatic thioester synthesis in a continuous flow microreactor.

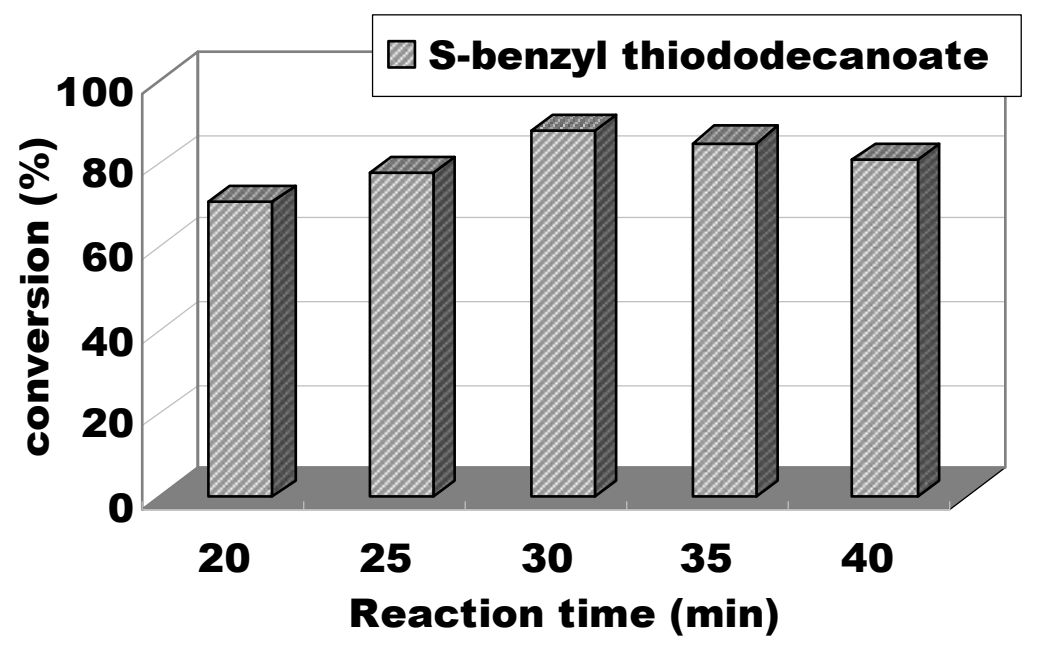

Figure 4. The influence of reaction time ( $\mathrm{min}$ ) on the enzymatic synthesis of thioesters in a continuous flow microreactor.

\subsection{Benzyl Mercaptan Donor Structure Effect}

Having obtained the favorable results given above, we then investigated the substrate structure effect on the enzymatic thioesters synthesis reaction in a microreactor. The effect of different substituted 
groups on the benzyl mercaptan was examined, as shown in Figure 5. Reaction of 4-methylbenzyl mercaptan (1b) to vinyl laurate (2b) afforded a higher yield (94\%, entry 6) than benzyl mercaptan (88\%, entry 2) (Scheme 1) in a short time, indicating that an electron-donating group improves the transesterification reactivity of the benzyl mercaptan. Oppositely, the reaction of 4-chlorobenzyl mercaptan (1c) and vinyl esters afforded a lower yield (entries 9-12). Under the same condition, the thioesters synthesis of benzyl mercaptan and vinyl laurate was more rapid than that using 4-chlorobenzyl mercaptan as the reactant, while lower than that using 4-methylbenzyl mercaptan as the donor.

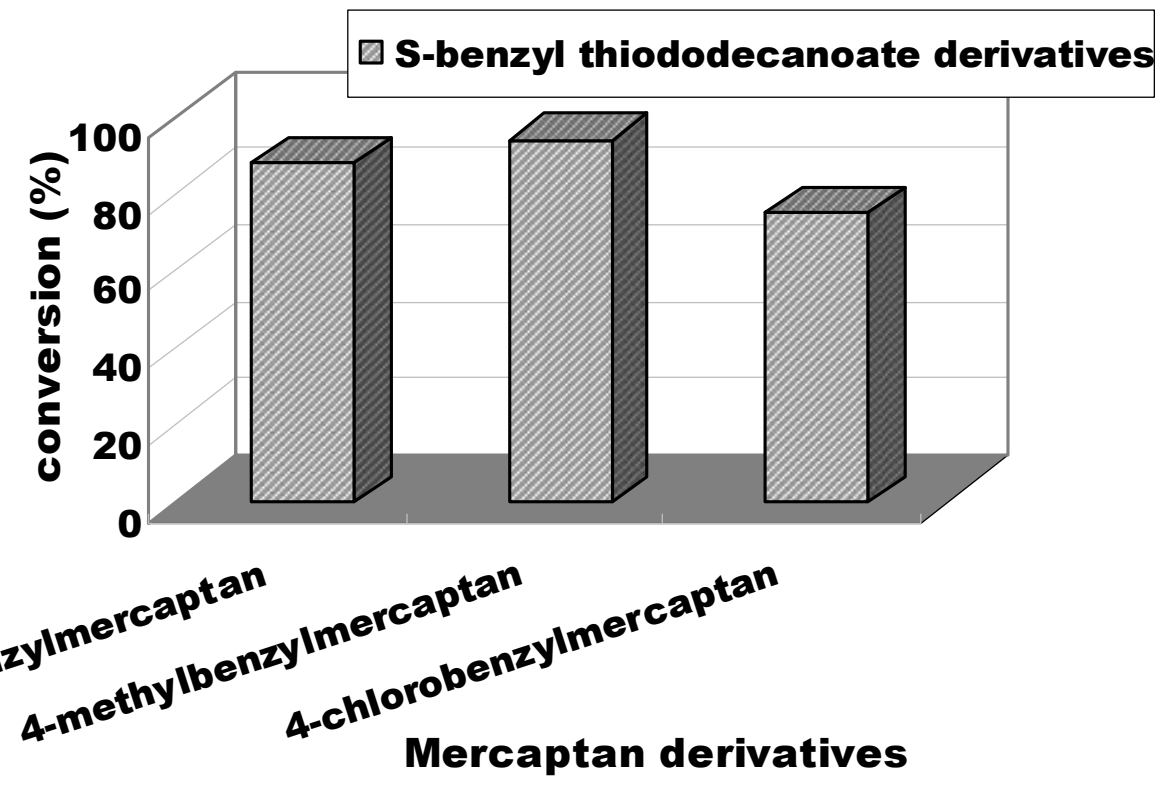

Figure 5. The effect of different substituted groups on benzyl mercaptan on the enzymatic synthesis of thioesters in a continuous flow microreactor. $10.4 \mu \mathrm{L} \mathrm{min}{ }^{-1}$ feed 1 (4 mmol thiol derivatives in $10 \mathrm{~mL} \mathrm{DMSO}$ ) and $10.4 \mu \mathrm{L} \mathrm{min}^{-1}$ feed 2 (8 mmol vinyl esters in $10 \mathrm{~mL} \mathrm{DMSO}$ ) at $50{ }^{\circ} \mathrm{C}$ (residence time $30 \mathrm{~min})$, Lipozyme TL IM $\left(0.87 \mathrm{~g}, 44 \mathrm{mg} \mathrm{mL}^{-1}\right)$.

\subsection{Vinyl Ester Acceptor Structure Effect}

We have also investigated the acceptor structure effect on the enzymatic thioester synthesis and found the longer the vinyl ester carboxyl group chain, the higher the conversion. Using benzyl mercaptan as the donor, the decrease of conversion was detected with the increase of carboxyl group chain. The conversion yield was less than $65 \%$ in the reaction of benzyl mercaptan and vinyl acetate (Figure 6).

Finally, to explore the scope and limitations of this new synthetic approach in a continuous-flow microreactor, three thiol derivatives, benzyl mercaptan (1a), 4-methylbenzyl mercaptan (1b), and 4-chlorobenzyl mercaptan (1c), and four vinyl esters (2a-d), were subjected to the general reaction conditions, using both a single-mode shaker reactor and a continuous-flow microreactor (Scheme 1). For the shaker experiments, reaction time needed about $24 \mathrm{~h}$ or more to obtain ideal yields (Method A). Using lipase-catalysed thioesters synthesis reaction of thiol under continuous-flow conditions, 12 thioesters were synthesized in parallel in a single experiment at the same flow rate (Method B). The results were better with flow microreactor processing than with the single-mode shaker (Table 1, entries 1-12). Importantly, applying flow microreactor processing, yielded a conversion of thioester derivatives to $82 \%$ or more. This allows us to reduce the reaction time and simplify the purification of products. 


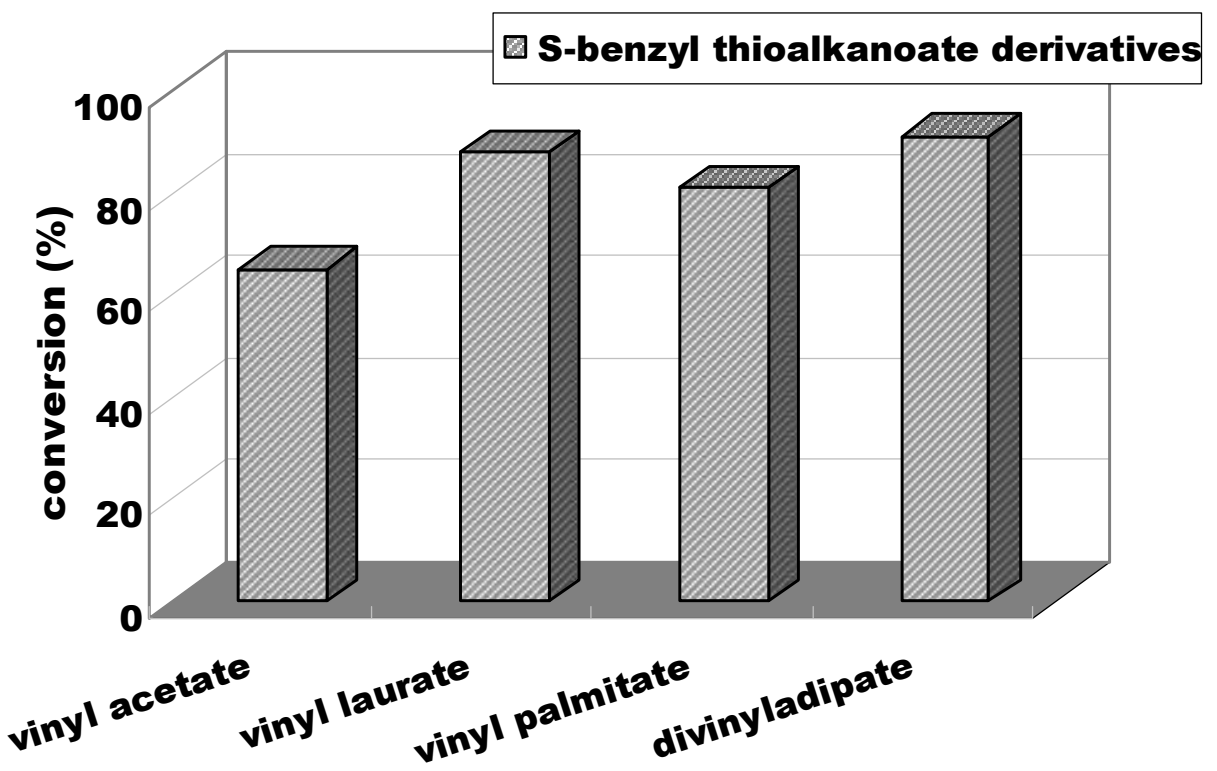

Figure 6. The effect of acceptor structures on the enzymatic synthesis of thioesters in a continuous flow microreactor. $10.4 \mu \mathrm{L} \mathrm{min}{ }^{-1}$ feed 1 ( $4 \mathrm{mmol}$ thiol derivatives in $10 \mathrm{~mL} \mathrm{DMSO}$ ) and $10.4 \mu \mathrm{L} \mathrm{min}{ }^{-1}$ feed 2 ( $8 \mathrm{mmol}$ vinyl esters in $10 \mathrm{~mL} \mathrm{DMSO}$ ) at $50^{\circ} \mathrm{C}$ (residence time $30 \mathrm{~min}$ ), Lipozyme TL IM ( $0.87 \mathrm{~g}$, $\left.44 \mathrm{mg} \mathrm{mL}^{-1}\right)$.

\section{Materials and Methods}

\subsection{Materials}

Unless otherwise stated, all chemicals were obtained from commercial sources and used without further purification. Lipase TL IM from Thermomyces lanuginosus was purchased from Novo Nordisk (Copenhagen, Denmark). Vinyl acetate (>99\%), vinyl laurate (>99\%), vinyl palmitate (>96\%), and divinyladipate (>96\%) were all purchased from Tokyo Chemical Industry Co., LTD. (Tokyo, Japan). Benzyl mercaptan (98\%), 4-methylbenzyl mercaptan (97\%), and 4-chlorobenzyl mercaptan (98\%) were all purchased from Aladdin (Shanghai, China). Harvard Apparatus PHD 2000 syringe pumps were purchased from Harvard Apparatus (Cambridge, MA, USA).

\subsection{Thioester Synthesis Operating Conditions}

\subsubsection{General Procedure for Thioesters Synthesis under Shaker Conditions}

Method A: Benzyl mercaptan $(1 \mathrm{mmol})$ and vinyl laurate $(3 \mathrm{mmol})$ were added to $5 \mathrm{~mL}$ DMSO. The biocatalyst lipozyme TL IM $\left(44 \mathrm{mg} \mathrm{mL}^{-1}, 0.22 \mathrm{~g}\right)$ was then added and the suspension maintained at $50{ }^{\circ} \mathrm{C}$ for $24 \mathrm{~h}$ under Shaker Conditions. The mixture was cooled and filtered. Then evaporated under reduced pressure and the residue was submitted to column chromatography on silica gel (200-300 mesh). The products were eluted with a gradient of normal petroleum ether/ethyl acetate (20:1, by vol). The purification was monitored by TLC. The fractions containing the main products were pooled, the solvent evaporated, and the residue analysed by ${ }^{1} \mathrm{H}$ NMR, ${ }^{13} \mathrm{C}$ NMR, and ESI-MS.

\subsubsection{General Procedure for Thioester Synthesis in Continuous Flow Microreactors}

Method B: Four millimoles of the benzyl mercaptan were dissolved in $10 \mathrm{~mL}$ DMSO (feed 1) and $8 \mathrm{mmol}$ vinyl laurate were dissolved in $10 \mathrm{~mL}$ DMSO (feed 2). Lipozyme TL IM (0.87 g) was weighed, then filled the PFA reactor coil (inner diameter ID: $2.0 \mathrm{~mm}$, length: $1 \mathrm{~m}$ ). Feeds 1 and 2 were mixed together at a flow rate of $10.4 \mu \mathrm{L} \mathrm{min}{ }^{-1}$ in a Y-mixer at $50{ }^{\circ} \mathrm{C}$, and the resulting stream $\left(20.8 \mu \mathrm{L} \min ^{-1}\right)$ was connected to a sample vial which was used to collect the final mixture. The final 
mixture was then evaporated, and the residue was submitted to column chromatography on silica gel (200-300 mesh). The products were eluted with a gradient of normal petroleum ether/ethyl acetate (20:1, by vol). The purification was monitored by TLC. The fractions containing the main products were pooled, the solvent evaporated, and the residue analysed by ${ }^{1} \mathrm{H} \mathrm{NMR},{ }^{13} \mathrm{C} N M R$, and ESI-MS. In order to examine the reproducibility of the method, we repeated the reaction five times, the result are illustrate in Figure S1.

\subsection{Analytical Methods}

\subsubsection{Thin-Layer Chromatography}

Analytical TLC was performed on silica gel 60 plates (Yantai Jiangyou Silicone Development Co., LTD., Yantai, China) using petroleum ether/ethyl acetate (20:1, by vol) as the eluent. Spots were detected by ultraviolet irradiation at $254 \mathrm{~nm}$.

\subsubsection{High-Performance Liquid Chromatography (HPLC)}

The reaction was monitored by HPLC analysis using a $4.6 \times 250 \mathrm{~mm}, 5 \mu \mathrm{m}$ XBridge C18 column with a gradient of methanol/water. For the analysis of products, methanol/water: 85/15 $(v / v)$ was used as the mobile phase (flow rate, $0.6 \mathrm{~mL} \mathrm{~min}^{-1}$ ), thiol and thioester derivatives were detected at $254 \mathrm{~nm}$. The conversion yield was defined as the ratio between the molar concentration of thioester derivatives and the initial molar concentration of the thiol derivatives used.

\subsubsection{Nuclear Magnetic Resonance (NMR) Analysis}

After purification of the synthesized products by column chromatography, the chemical structures of thioesters were determined by ${ }^{1} \mathrm{H}$ NMR, ${ }^{13} \mathrm{C}$ NMR and ESI-MS.

S-Benzyl thioacetate (3a): Light yellow oil; ${ }^{1} \mathrm{H}$ NMR $\left(500 \mathrm{MHz}, \mathrm{CDCl}_{3}\right): \delta 7.32-7.26(\mathrm{~m}, 5 \mathrm{H}), 4.15$ (s, 2H), 2.37 (s, 3H). ${ }^{13} \mathrm{C}$ NMR (125 MHz, $\left.\mathrm{CDCl}_{3}\right): \delta 195.0,137.6,128.8,128.6,127.2,33.4$, 30.2. ESI-MS: $m / z=189.1[\mathrm{M}+\mathrm{Na}]^{+}$.

S-Benzyl thiododecanoate (3b): White crystals; ${ }^{1} \mathrm{H}$ NMR $\left(500 \mathrm{MHz}, \mathrm{CDCl}_{3}\right): \delta 7.36-7.27(\mathrm{~m}, 5 \mathrm{H}), 4.17(\mathrm{~s}$, $2 \mathrm{H}), 2.61(\mathrm{t}, J=7.5 \mathrm{~Hz}, 2 \mathrm{H}), 1.73(\mathrm{~m}, 2 \mathrm{H}), 1.35(\mathrm{~m}, 16 \mathrm{H}), 0.98(\mathrm{t}, J=6.0 \mathrm{~Hz}, 3 \mathrm{H}) .{ }^{13} \mathrm{C} \mathrm{NMR}(125 \mathrm{MHz}$, $\left.\mathrm{CDCl}_{3}\right): \delta 198.2,137.7,128.6,128.4,127.0,43.6,32.9,31.8,29.5,29.4-29.1,28.8,25.5,22.6,14.0$. ESI-MS: $m / z=329.2[\mathrm{M}+\mathrm{Na}]^{+}$.

S-Benzyl thiohexadecanoate (3c): White solid; ${ }^{1} \mathrm{H}$ NMR (500 MHz, $\left.\mathrm{CDCl}_{3}\right): \delta 7.34-7.25(\mathrm{~m}, 5 \mathrm{H}), 4.14$ $(\mathrm{s}, 2 \mathrm{H}), 2.58(\mathrm{t}, J=7.5 \mathrm{~Hz}, 2 \mathrm{H}), 1.66(\mathrm{~m}, 2 \mathrm{H}), 1.47-1.23(\mathrm{~m}, 24 \mathrm{H}), 0.91(\mathrm{t}, J=7.0 \mathrm{~Hz}, 3 \mathrm{H}) .{ }^{13} \mathrm{C}$ NMR $\left(125 \mathrm{MHz}, \mathrm{CDCl}_{3}\right): \delta$ 198.9, 137.8, 129.3, 129.0, 128.8, 128.6, 127.2, 43.9, 33.1, 31.9, 29.7, 29.6-29.1, 29.0, 25.6, 22.7, 14.1. ESI-MS: $m / z=385.2[\mathrm{M}+\mathrm{Na}]^{+}$.

6-oxo-6-((Benzyl)thio)-hexanoate vinyl ester (3d): Yellow oil; ${ }^{1} \mathrm{H} \mathrm{NMR}\left(500 \mathrm{MHz}, \mathrm{CDCl}_{3}\right)$ : $\delta 7.35-7.24(\mathrm{~m}$, $6 \mathrm{H}), 4.89(\mathrm{ddd}, J=14.0,3.4,1.6 \mathrm{~Hz}, 1 \mathrm{H}), 4.59(\mathrm{ddd}, J=6.3,2.4,1.7 \mathrm{~Hz}, 1 \mathrm{H}), 4.14(\mathrm{~s}, 2 \mathrm{H}), 2.59(\mathrm{~m}, 2 \mathrm{H})$, $2.43(\mathrm{~m}, 2 \mathrm{H}), 1.72(\mathrm{~m}, 4 \mathrm{H}) .{ }^{13} \mathrm{C}$ NMR $\left(125 \mathrm{MHz}, \mathrm{CDCl}_{3}\right): \delta 198.1,170.1,141.1,137.5,128.7,128.6,127.2$, 97.6, 43.2, 33.4, 33.1, 24.7, 23.8. ESI-MS: $m / z=301.1[\mathrm{M}+\mathrm{Na}]^{+}$.

S-(4-Methylbenzyl) ethanethioate (3e): Light yellow oil; ${ }^{1} \mathrm{H}$ NMR $\left(500 \mathrm{MHz}, \mathrm{CDCl}_{3}\right): \delta 7.19(\mathrm{~d}, J=7.6 \mathrm{~Hz}$, 2H), $7.12(\mathrm{~d}, J=7.6 \mathrm{~Hz}, 2 \mathrm{H}), 4.10(\mathrm{~s}, 2 \mathrm{H}), 2.35(\mathrm{~s}, 3 \mathrm{H}), 2.33(\mathrm{~s}, 3 \mathrm{H}) .{ }^{13} \mathrm{C} \mathrm{NMR}\left(125 \mathrm{MHz}, \mathrm{CDCl}_{3}\right): \delta$ 195.0, $137.9,134.2,129.8,129.7,33.4,30.2$, 21.1. ESI-MS: $m / z=203.1[\mathrm{M}+\mathrm{Na}]^{+}$.

S-(4-Methylbenzyl) thiododecanoate (3f): Yellow liquid oil; ${ }^{1} \mathrm{H}$ NMR $\left(500 \mathrm{MHz}, \mathrm{CDCl}_{3}\right): \delta 7.18(\mathrm{~d}$, $J=7.6 \mathrm{~Hz}, 2 \mathrm{H}), 7.12(\mathrm{~d}, J=7.6 \mathrm{~Hz}, 2 \mathrm{H}), 4.10(\mathrm{~s}, 2 \mathrm{H}), 2.57(\mathrm{t}, J=7.5 \mathrm{~Hz}, 2 \mathrm{H}), 2.33(\mathrm{~s}, 3 \mathrm{H}), 1.64(\mathrm{~m}, 2 \mathrm{H})$, $1.31(\mathrm{~m}, 16 \mathrm{H}), 0.89(\mathrm{t}, J=7.1 \mathrm{~Hz}, 3 \mathrm{H}) .{ }^{13} \mathrm{C} \mathrm{NMR}\left(125 \mathrm{MHz}, \mathrm{CDCl}_{3}\right): \delta 199.1,137.0,134.7,129.4,128.8$, $43.9,32.9,32.0,29.7,29.6-29.3,29.0,25.7,22.8,21.1,14.2$. ESI-MS: $\mathrm{m} / z=343.2[\mathrm{M}+\mathrm{Na}]^{+}$. 
S-(4-Methylbenzyl) thiohexadecanoate (3g): Light yellow oil; ${ }^{1} \mathrm{H}$ NMR $\left(500 \mathrm{MHz}, \mathrm{CDCl}_{3}\right): \delta 7.19$ (d, $J=8.0 \mathrm{~Hz}, 2 \mathrm{H}), 7.12(\mathrm{~d}, J=7.9 \mathrm{~Hz}, 2 \mathrm{H}), 4.10(\mathrm{~s}, 2 \mathrm{H}), 2.56(\mathrm{t}, J=7.5 \mathrm{~Hz}, 2 \mathrm{H}), 2.34(\mathrm{~s}, 3 \mathrm{H}), 1.68(\mathrm{~m}, 2 \mathrm{H})$, $1.32-1.27(\mathrm{~m}, 24 \mathrm{H}), 0.90(\mathrm{t}, J=7.0 \mathrm{~Hz}, 3 \mathrm{H}) .{ }^{13} \mathrm{C} \mathrm{NMR}\left(125 \mathrm{MHz}, \mathrm{CDCl}_{3}\right): \delta 199.0,136.9,134.7,129.3$, $128.7,43.9,32.9,32.0,29.7,29.6-29.3,29.0,25.6,22.7,21.1,14.1$. ESI-MS: $m / z=399.3[\mathrm{M}+\mathrm{Na}]^{+}$.

6-oxo-6-((4-Methylbenzyl)thio)-hexanoate vinyl ester (3h): Light yellow oil; ${ }^{1} \mathrm{H} \mathrm{NMR}\left(500 \mathrm{MHz}, \mathrm{CDCl}_{3}\right): \delta$ $7.31-7.20(\mathrm{~m}, 5 \mathrm{H}), 4.87(\mathrm{ddd}, J=14.0,3.3,1.7 \mathrm{~Hz}, 1 \mathrm{H}), 4.56(\mathrm{ddd}, J=6.2,2.0,1.7 \mathrm{~Hz}, 1 \mathrm{H}), 4.11(\mathrm{~s}, 2 \mathrm{H})$, $2.59(\mathrm{~m}, 2 \mathrm{H}), 2.41(\mathrm{~m}, 2 \mathrm{H}), 2.39(\mathrm{~s}, 3 \mathrm{H}), 1.71(\mathrm{~m}, 4 \mathrm{H}) .{ }^{13} \mathrm{C} \mathrm{NMR}\left(125 \mathrm{MHz}, \mathrm{CDCl}_{3}\right): \delta 198.0,170.1,141.0$, 137.5, 128.7, 128.5, 127.2, 97.6, 43.1, 33.4, 33.1, 24.7, 23.8, 23.7. ESI-MS: $m / z=315.1[\mathrm{M}+\mathrm{Na}]^{+}$.

S-(4-Chlorobenzyl) ethanethioate (3i): Light yellow oil; ${ }^{1} \mathrm{H} \mathrm{NMR}\left(500 \mathrm{MHz}, \mathrm{CDCl}_{3}\right): \delta 7.27(\mathrm{dd}, J=8.6,6.6$ $\mathrm{Hz}, 2 \mathrm{H}), 7.23(\mathrm{dd}, J=8.5,6.1 \mathrm{~Hz}, 2 \mathrm{H}), 4.08(\mathrm{~s}, 2 \mathrm{H}), 2.36(\mathrm{~s}, 3 \mathrm{H}) .{ }^{13} \mathrm{C} \mathrm{NMR}\left(125 \mathrm{MHz}, \mathrm{CDCl}_{3}\right): \delta$ 195.0, 135.7, 132.7, 130.8, 128.8, 33.1, 30.5. ESI-MS: $m / z=223.0[\mathrm{M}+\mathrm{Na}]^{+}$.

S-(4-Chlorobenzyl) thiododecanoate (3j): Yellow liquid oil; ${ }^{1} \mathrm{H}$ NMR $\left(500 \mathrm{MHz}, \mathrm{CDCl}_{3}\right): \delta 7.27(\mathrm{dd}, J=8.5$, $6.5 \mathrm{~Hz}, 2 \mathrm{H}), 7.23(\mathrm{dd}, J=8.5,6.0 \mathrm{~Hz}, 2 \mathrm{H}), 4.08(\mathrm{~s}, 2 \mathrm{H}), 2.57(\mathrm{t}, J=7.2 \mathrm{~Hz}, 2 \mathrm{H}), 1.66(\mathrm{~m}, 2 \mathrm{H}), 1.29(\mathrm{~m}$, $16 \mathrm{H}), 0.90(\mathrm{t}, J=6.0 \mathrm{~Hz}, 3 \mathrm{H}) .{ }^{13} \mathrm{C}$ NMR $\left(125 \mathrm{MHz}, \mathrm{CDCl}_{3}\right): \delta 198.7,141.2,136.5,133.0,130.2,128.7,43.8$, 34.0, 32.4, 31.9, 29.6-29.0, 28.9, 25.6, 24.6, 22.7, 14.1. ESI-MS: $m / z=363.2[\mathrm{M}+\mathrm{Na}]^{+}$.

S-(4-Chlorobenzyl) thiohexadecanoate (3k): Yellow oil; ${ }^{1} \mathrm{H}$ NMR $\left(500 \mathrm{MHz}, \mathrm{CDCl}_{3}\right): \delta 7.27(\mathrm{dd}, J=8.4$, $6.3 \mathrm{~Hz}, 2 \mathrm{H}), 7.23(\mathrm{dd}, J=8.3,6.0 \mathrm{~Hz}, 2 \mathrm{H}), 4.23(\mathrm{~s}, 2 \mathrm{H}), 2.58(\mathrm{t}, J=7.5 \mathrm{~Hz}, 2 \mathrm{H}), 1.78(\mathrm{~d}, J=7.1 \mathrm{~Hz}, 2 \mathrm{H})$, $1.58-1.32(\mathrm{~m}, 24 \mathrm{H}), 0.89(\mathrm{t}, J=6.8 \mathrm{~Hz}, 3 \mathrm{H}) .{ }^{13} \mathrm{C}$ NMR $\left(125 \mathrm{MHz}, \mathrm{CDCl}_{3}\right): \delta 199.0,135.9,132.8,131.9$, $131.7,129.2,128.8,44.2,33.6,32.9,30.1,29.8-29.2,28.0,26.5,23.4,14.9$. ESI-MS: $m / z=419.2[\mathrm{M}+\mathrm{Na}]^{+}$. 6-oxo-6-((4-Chlorobenzyl)thio)-hexanoate vinyl ester (31): Yellow oil; ${ }^{1} \mathrm{H}$ NMR $\left(500 \mathrm{MHz}, \mathrm{CDCl}_{3}\right)$ : $\delta$ $7.32-7.20(\mathrm{~m}, 5 \mathrm{H}), 4.89(\mathrm{ddd}, J=14.0,3.4,1.6 \mathrm{~Hz}, 1 \mathrm{H}), 4.59(\mathrm{ddd}, J=6.3,2.4,1.6 \mathrm{~Hz}, 1 \mathrm{H}), 4.08(\mathrm{~s}, 2 \mathrm{H})$, $2.61(\mathrm{~m}, 2 \mathrm{H}), 2.41(\mathrm{~m}, 2 \mathrm{H}), 1.72(\mathrm{~m}, 4 \mathrm{H}) .{ }^{13} \mathrm{C} \mathrm{NMR}\left(125 \mathrm{MHz}, \mathrm{CDCl}_{3}\right): \delta$ 198.0, 170.2, 141.1, 136.3, 133.1, $130.2,128.8,97.7,43.2,33.4,32.5,24.8,23.8$. ESI-MS: $m / z=335.1[\mathrm{M}+\mathrm{Na}]^{+}$.

\section{Conclusions}

In conclusion, we describe here the enzymatic synthesis of thioesters from thiols and vinyl esters in a continuous-flow microreactor. The reaction conditions including reaction temperature, reaction time/flow rate, substrate molar ratio and the substrate structure effect on the reaction were examined. The scope of the reaction was tested by varying the thiols and vinyl esters. Compared to traditional batch processes, continuous-flow microreactor technology offers a variety of advantages, such as reduced reaction times, improved operational safety and much lower process costs and increased process efficiency. The salient features of this method include mild reaction conditions $\left(50{ }^{\circ} \mathrm{C}\right)$, short reaction times (30 $\mathrm{min}$ ), and high yields that make our methodology a valuable contribution to the thioester derivatives synthesis. The method of enzymatic synthesis in a microreactor environment described here may have general applications to synthetic organic chemistry by enzymatic catalysis in the future. Thioester derivatives synthesis of thiophenol, furanthiol, thienyl mercaptan, and other sulphur nucleophiles to vinyl esters catalysed by lipase TL IM from Thermomyces lanuginosus in a continuous-flow microreactor are in progress.

Supplementary Materials: The following are available online at http:/ /www.mdpi.com/2073-4344/8/6/249/s1, Figure S1: The reproducibility of the reaction on the conversion of S-Benzyl thiododecanoate catalysed by Lipozyme TL IM in a continuous flow microreactor.

Author Contributions: L.D. and L.S. conceived and designed the experiments. L.S., Z.D., and N.Z. performed the experiments. L.D., L.S., and J.S. analysed the data. L.D. and X.L. contributed reagents/materials/analysis tools. L.D., L.S., J.S., Z.D., and N.Z. wrote or reviewed the manuscript.

Funding: This research was funded by the Natural Science Foundation of Zhejiang Province grant number [LY17B020010], the National Science and Technology Support Project grant number [2015BAD14B0305], the International Cooperation Project 948 grant number [2014-4-29], the National Natural Science Foundation of China grant number [2130617], the Science and Technology Research Program of Zhejiang Province grant number 
[2014C32094], as well as the Natural Science Foundation of Zhejiang University of Technology grant number [116004029] and the APC was funded by Zhejiang Province grant number [LY17B020010].

Acknowledgments: This work was supported by the Natural Science Foundation of Zhejiang Province (LY17B020010), the National Science and Technology Support Project (2015BAD14B0305), the International Cooperation Project 948 (2014-4-29), the National Natural Science Foundation of China (21306172), the Science and Technology Research Program of Zhejiang Province (2014C32094), as well as the Natural Science Foundation of Zhejiang University of Technology (116004029) for financial support.

Conflicts of Interest: The authors declare no conflict of interest.

\section{References}

1. Fuse, S.; Mifune, Y.; Takahashi, T. Efficient amide bond formation through a rapid and strong activation of carboxylic acids in a microflow reactor. Angew. Chem. Int. Ed. 2014, 53, 851-855. [CrossRef] [PubMed]

2. Jadhav, A.S.; Anand, R.V. 1,6-Conjugate addition of zinc alkyls to para-quinone methides in a continuous-flow microreactor. Org. Biomol. Chem. 2017, 15, 56-60. [CrossRef] [PubMed]

3. Cambie, D.; Bottecchia, C.; Straathof, N.J.W.; Hessel, V.; Noel, T. Applications of continuous-flow photochemistry in organic synthesis, material science, and water treatment. Chem. Rev. 2016, 116, 10276-10341. [CrossRef] [PubMed]

4. Atodiresei, I.; Vila, C.; Rueping, M. Asymmetric organocatalysis in continuous flow: Opportunities for impacting industrial catalysis. ACS Catal. 2015, 5, 1972-1985. [CrossRef]

5. Haven, J.J.; Vandenbergh, J.; Junkers, T. Watching polymers grow: Real time monitoring of polymerizations via an on-line ESI-MS/microreactor coupling. Chem. Commun. 2015, 51, 4611-4614. [CrossRef] [PubMed]

6. Trombettoni, V.; Bianchi, L.; Zupanic, A.; Porciello, A.; Cuomo, M.; Piermatti, O.; Marrocchi, A.; Vaccaro, L. Efficient catalytic upgrading of levulinic acid into alkyl levulinates by resin-supported acids and flow reactors. Catalysts 2017, 7, 235-248. [CrossRef]

7. Nagaki, A.; Takahashi, Y.; Yoshida, J. Extremely fast gas/liquid reactions in flow microreactors: Carboxylation of short-lived organolithiums. Chem. Eur. J. 2014, 20, 7931-7934. [CrossRef] [PubMed]

8. He, Z.; Jamison, T.F. Continuous-Flow Synthesis of Functionalized Phenols by Aerobic Oxidation of Grignard Reagents. Angew. Chem. Int. Ed. 2014, 53, 3353-3357. [CrossRef] [PubMed]

9. Iemhoff, A.; Sherwood, J.; McElroya, C.R.; Hunt, A.J. Towards sustainable kinetic resolution, a combination of bio-catalysis, flow chemistry and bio-based solvents. Green Chem. 2018, 20, 136-140. [CrossRef]

10. Du, L.H.; Shen, J.H.; Dong, Z.; Zhou, N.N.; Cheng, B.Z.; Ou, Z.M.; Luo, X.P. Enzymatic synthesis of nucleoside analogues from uridines and vinyl esters in a continuous-flow microreactor. RSC Adv. 2018, 8, 12614-12618. [CrossRef]

11. Du, L.H.; Jiang, Z.P.; Xu, L.L.; Zhou, N.N.; Shen, J.H.; Dong, Z.; Shen, L.; Wang, H.; Luo, X.P. Microfluidic reactor for lipase-catalyzed regioselective synthesis of neohesperidin ester derivatives and their antimicrobial activity research. Carbohydr. Res. 2018, 455, 32-38. [CrossRef] [PubMed]

12. Bi, Y.; Zhou, H.; Jia, H.; Wei, P. Polydopamine-mediated preparation of an enzyme-immobilized microreactor for the rapid production of wax ester. RSC Adv. 2017, 7, 12283-12291. [CrossRef]

13. Kundu, S.; Bhangale, A.S.; Wallace, W.E.; Flynn, K.M.; Guttman, C.M.; Gross, R.A.; Beers, K.L. Continuous Flow Enzyme-Catalyzed Polymerization in a Microreactor. J. Am. Chem. Soc. 2011, 133, 6006-6011. [CrossRef] [PubMed]

14. Nagaki, A.; Ichinari, D.; Yoshida, J. Reactions of organolithiums with dialkyl oxalates. A flow microreactor approach to synthesis of functionalized a-keto esters. Chem. Commun. 2013, 49, 3242-3244. [CrossRef] [PubMed]

15. Ferreira, L.M.C.; Costa, E.T.D.; Lago, C.L.D.; Angnes, L. Miniaturized flow system based on enzyme modified PMMA microreactor for amperometric determination of glucose. Biosens. Bioelectron. 2013, 47, 539-544. [CrossRef] [PubMed]

16. Du, L.H.; Ling, H.M.; Luo, X.P. Michael addition of pyrimidine derivatives with acrylates catalyzed by lipase TL IM from Thermomyces lanuginosus in a continuous-flow microreactor. RSC Adv. 2014, 4, 7770-7773. [CrossRef]

17. Du, L.H.; Cheng, B.Z.; Yang, W.J.; Xu, L.L.; Luo, X.P. Markovnikov addition of imidazole derivatives with vinyl esters catalyzed by lipase TL IM from Thermomyces lanuginosus $/ \mathrm{K}_{2} \mathrm{CO}_{3}$ in a continuous-flow microreactor. RSC Adv. 2016, 6, 59100-59103. [CrossRef] 
18. Du, L.H.; Luo, X.P. Lipase-catalyzed regioselective acylation of sugar in microreactors. RSC Adv. 2012, 2, 2663-2665. [CrossRef]

19. Luo, X.P.; Du, L.H.; He, F.; Zhou, C.H. Controllable regioselective acylation of flavonoids catalyzed by lipase in microreactors. J. Carbohyd. Chem. 2013, 32, 450-462. [CrossRef]

20. Carvalho, F.; Marques, M.P.C.; Fernandes, P. Sucrose hydrolysis in a bespoke capillary wall-coated microreactor. Catalysts 2017, 7, 42-59. [CrossRef]

21. Yan, K.L.; Yang, D.S.; Wei, W.; Zhao, J.; Shuai, Y.Y.; Tian, L.J.; Wang, H. Catalyst-free direct decarboxylative coupling of $\alpha$-keto acids with thiols: A facile access to thioesters. Org. Biomol. Chem. 2015, 13, 7323-7330. [CrossRef] [PubMed]

22. Singh, P.; Peddinti, R.K. Harnessing the catalytic behaviour of 1,1,1,3,3,3-hexafluoro-2-propanol (HFIP): An expeditious synthesis of thioesters. Tetrahedron Lett. 2017, 58, 1875-1878. [CrossRef]

23. Wang, Y.; Huang, G.; Hu, S.; Jin, K.J.; Wu, Y.; Chen, F. Enantioselective $\beta$-hydroxy thioesters formation via decarboxylative aldol reactions of malonic acid half thioesters with aldehydes promoted by chloramphenicol derived sulfonamides. Tetrahedron 2017, 73, 5055-5062. [CrossRef]

24. Qiao, Z.J.; Jiang, X.F. Ligand-controlled divergent cross-coupling involving organosilicon compounds for thioether and thioester synthesis. Org. Lett. 2016, 18, 1550-1553. [CrossRef] [PubMed]

25. Kazemi, M.; Kohzadi, H.; Noori, Z. Potassium carbonate: A highly efficient catalyst for the acylation of alcohols, phenols and thiols under mild conditions. Iran. Chem. Commun. 2014, 2, 39-47.

26. Asahina, Y.; Kawakami, T.; Hojo, H. One-pot native chemical ligation by combination of two orthogonal thioester precursors. Chem. Commun. 2017, 53, 2114-2117. [CrossRef] [PubMed]

27. Eto, M.; Naruse, N.; Morimoto, K.; Yamaoka, K. Development of an Anilide-Type Scaffold for the Thioester Precursor N-Sulfanylethylcoumarinyl Amide. Org. Lett. 2016, 18, 4416-4419. [CrossRef] [PubMed]

28. Elashal, H.E.; Sim, Y.E.; Raj, M. Serine promoted synthesis of peptide thioesterprecursor on solid support for native chemical ligation. Chem. Sci. 2017, 8, 117-123. [CrossRef] [PubMed]

29. Konieczynska, M.D.; Villa-Camacho, J.C.; Ghobril, C. On-demand dissolution of a dendritic hydrogel-based dressing for second-degree burn wounds through thiol-thioester exchange reaction. Angew. Chem. Int. Ed. 2016, 55, 9984-9987. [CrossRef] [PubMed]

30. Chou, Y.L.; Jhong, Y.; Swain, S.P.; Hou, D.R. Application of enzyme-immobilization technique for microflow reactor. J. Org. Chem. 2017, 82, 10201-10208. [CrossRef] [PubMed]

31. Chen, J.A.; Yuan, P.F.; Wang, L.M.; Huang, Y. Enantioselective $\beta$-protonation of enals via a shuttling strategy. J. Am. Chem. Soc. 2017, 139, 7045-7051. [CrossRef] [PubMed]

32. Downey, C.W.; Ingersoll, J.A.; Glist, H.M. One-pot silyl ketene acetal-formation Mukaiyama-mannich additions to imines mediated by trimethylsilyl trifluoromethanesulfonate. Eur. J. Org. Chem. 2015, 1015, 7287-7291. [CrossRef]

33. Bello, D.; O'Hagan, D. Lewis acid-promoted hydrofluorination of alkynyl sulfides to generate $\alpha$-fluorovinyl thioethers. Beilstein J. Org. Chem. 2015, 11, 1902-1909. [CrossRef] [PubMed]

34. Kazemi, M.; Shiri, L. Thioesters synthesis: Recent adventures in the esterification of thiols. J. Sulfur. Chem. 2015, 36, 613-623. [CrossRef]

35. Zhang, W.; Zhao, Z.; Wang, Z.; Guo, C.; Wang, C.; Zhao, R.; Wang, L. Lipase-catalyzed synthesis of indolyl $4 \mathrm{H}$-chromenes via a multicomponent reaction in ionic liquid. Catalysts 2017, 7, 185-194. [CrossRef]

36. Guo, F.; Berglund, P. Transaminase biocatalysis: Optimization and application. Green Chem. 2017, 19, 333-360. [CrossRef]

37. Gonzalo, G.D.; Fürst, M.J.L.J.; Fraaije, M.W. Polycyclic ketone monooxygenase (Pockemo): A robust biocatalyst for the synthesis of optically active sulfoxides. Catalysts 2017, 7, 288-297. [CrossRef]

38. Patel, V.; Gajera, H.; Gupta, A.; Manocha, L.; Madamwar, D. Synthesis of ethyl caprylate in organic media using Candida rugosa lipase immobilized on exfoliated graphene oxide: Process parameters and reusability studies. Biochem. Eng. J. 2015, 95, 62-70. [CrossRef]

39. Choi, J.M.; Han, S.S.; Kim, H.S. Industrial applications of enzyme biocatalysis: Current status and future aspects. Biotechnol. Adv. 2015, 33, 1443-1454. [CrossRef] [PubMed]

40. Sheldon, R.A.; Pelt, S.V. Enzyme immobilisation in biocatalysis: Why, what and how. Chem. Soc. Rev. 2013, 42, 6223-6235. [CrossRef] [PubMed] 
41. Nestl, B.M.; Hammer, S.C.; Nebel, B.A.; Hauer, B. New generation of biocatalysts for organic synthesis. Angew. Chem. Int. Ed. 2014, 53, 3070-3095. [CrossRef] [PubMed]

42. Lou, F.W.; Liu, B.K.; Wang, J.L.; Pan, Q.; Lin, X.F. Controllable enzymatic Markovnikov addition and acylation of thiols to vinyl esters. J. Mol. Catal. B-Enzym. 2009, 60, 64-68. [CrossRef] 